\title{
Position of Verdict KPPU in Indonesia
}

\author{
N Yolanda ${ }^{1}$ \\ \{ninayolanda51@yahoo.co.id ${ }^{1}$ \} \\ ${ }^{1}$ FH.Universitas Palembang, Indonesia
}

\begin{abstract}
The phenomenon has grown and is supported by the presence of associated relations between the decision-makers with the party efforts, either directly or indirectly, that more aggravate in situation. The implementation of national economics lack spur to the mandate of the constitution that is Article 33 UUD 1945, as well as tends to show the pattern of a very monopolistic. The businessmen near with elite authorization get the eases of profuse that impact to asymmetry of social. The emergence of conglomerate and a small group of powerful employers that is not supported by the spirit of entrepreneurship is one of the factors that resulted in the resilience of the economy to be very fragile and not able to compete. The pay attention to the situation and the conditions mentioned above, demanding us to examine the fund reorganize business activities in Indonesia, so that businesses can grow and develop in a healthy and right, that create a climate of healthy competition, as well as avoiding concentration of economic power on individuals or specific groups, another in the form practical monopoly and competition efforts is not healthy of damage society with contradiction with ambition of justice. In the principle of verdict to made CSBC is not bound for parties dispute. Because in formal or normative $\mathrm{CSBC}$ is not competent made the verdict and given doubt that is the judiciary. If seen from the verdict remove, that is not included in the verdict condemnatory although the verdict of declarator. Therefore, the writer can be conclusion that position of the verdict removes by CSBC in system Indonesia of the law is not clear and confused. That is not clear because not arrange in distinct by Legislations, confuse because of the verdict can not input in the verdict condemnator although verdict declarator. The verdict to remove by CSBC only character entirely administrative not juridical technical that is verdict institute other outside the court that is verdict P4P, Bapepam, BPSK, institute Arbitration, etc.
\end{abstract}

Keywords: The Commission for the Supervision of Business Competition and Doubt.

\section{Introduction}

Development of the economy in Long-Term Development First (LTDF) has resulted more progress, another with increasing prosperity of society. Progress of development has achieved above, push by policy the development some sector, include policy of development in sector economy to pour in the Board Guidelines of State Policy (BGSP) and Five-Year Development Plan (FYDP), along with some the policy of economic other. 
Although has more progress to achieve during LTDF, the indication with grown high economic, but still more challenge and problems especially in the development economic is not solved, in a row with existence inclination globalization economics matters along with dynamic and development a business private.

The opportunity business to create for not making a decade ago in fact, the whole community able and can participate in the development of some economic sector. Development business private in period, on the one hand of color by various forms of the policy of the government is lacking right so that the market into distorted. Another side, development business private in the facts partly a big is realization from condition competition business is not healthy.

The phenomenon has grown and is supported by the presence of associated relations between the decision-makers with the party efforts, either directly or indirectly, that more aggravate in situation. The implementation of national economics lack spur to the mandate of the constitution that is Article 33 UUD 1945, as well as tends to show the pattern of a very monopolistic.

The businessmen near with elite authorization get the eases of profuse that impact to the asymmetry of social. The emergence of conglomerate and a small group of powerful employers that is not supported by the spirit of entrepreneurship is one of the factors that resulted in the resilience of the economy to be very fragile and not able to compete.

The pay attention to the situation and the conditions mentioned above, demanding us to examine the fund reorganize business activities in Indonesia, so that businesses can grow and develop in a healthy and right, that creates a climate of healthy competition, as well as avoiding concentration of economic power on individuals or specific groups, another in the form practical monopoly and competition efforts is not healthy of damage society with contradiction with ambition of justice[1]

Therefore, to supervise the practice monopoly and competition effort unhealthily should be formed institutions that have been instruction by the constitution that is the Commission for the Supervision of Business Competition(CSBC) for maintain regulation of the law and given protection same for every parties business in efforts to create competition business healthy. CSBC is an institution the independent in spite of the influence of the government and the other party, the authority to conduct supervision of business competition and to impose sanctions. The sanction in the form of administrative measures, whereas criminal sanctions are the authority the court.

In formal CSBC is an institution the independent in operating of duty. However along the existence of the institution is still questioned the status of law whether including the institution justice or not. Because in the Legislations No 5 of 1999 of the institution was not expressed assertively whether the authorities using irah-irahor not as it is the other justice.[2]

Along with it up, a very ironic is almost all the verdict CSBC canceled by The Court Country. The Administrative Court and Supreme Court. ${ }^{1}$.

This certain caused by a very basic, because it is from the beginning has been no obscurity the position of the law CSBC in the system the court in Indonesia.

${ }^{1}$ As an example stated in a paper by Dr. Iur Silalahi, SH., LLM. In a panel discussion on competition law \& practice on December 20, 2006 organized by CSIS, the Indomaret case and PT. Indomobil, the Supreme Court overturned the District Court's decision and at the same time canceled the KPPU's decision null and void by law. 
From the description of the author present in the background, that into problems in paperwork this is (1) How the position of the law verdict CSBC in system of the law Indonesia? (2)As far as where the remove by CSBC has the power of bind for the parties dispute?

\section{Method}

Type of the research in this writing paperwork is descriptions with normative approach. Main data resources are secondary data the writer from library informs regulation of constitution along with literature relate to problems. After all collect data, then to analyze the descriptive qualitative, so that what is the problem in the paper can be missed.

\subsection{Observation}

\section{a. The Observation of Review}

In various of the country in world,[2] handling of the case practice monopoly and competition business unhealthy handled by institution especially, for example in America Serikat implementation of Constitution Anti Monopoly implemented by The Justice of Departement dan Federal Trade Commission (FTC). In the practical, this both in collaboration and mutual complete in their duties carry out of Constitution Anti Monopoly.

In Japan, for perform of Constitution Anti Monopoly established (Fair Trade Commission), this commission in administration under the authority of the Prime Minister. However based on the determine of Constitution, Chairman of FTC and commission agent have freedom in operating duties maintain of the law anti-monopoly. Chairman and commission is person have skill in sector of the law and economy. The appointment and discharge chairman of FTC in confirmation by caesar Japan.

In Australia, implementation of Constitution Anti Monopoly implemented by (Trade Practice Commission/TPC). TPC gets mandate for operating of Constitution and have authority for carrying out an investigation, including investigation deign with complaint offense of Constitution Anti Monopoly.

In Jerman is responsible for the implementation of the Legislations Kartel is (Federal Carter Office/FCO) to founded by every the part of Country. The main of duty from (Federal Carter Office/FCO) is about problems to relate with restriction about competition of healthy in the part of Country. Especially investigation about merger of company handled by FCO in collaboration in independent. This office has nine division to each division have authority in sector economic of certain. With this, its office can resolve all the activities in sector economic and attitude of competition company from companies to work in sector it. The main of duties institute it is carried out investigation and collection of data from company of suspicious carry-out practice of business dishonest even on the permission the court competent for carrying out ransacking of company and confiscate a good of proving.[3]

How in Indonesia?, Based on the Legislations no 5 of 1999 about Prohibition of Monopoly and Practice of Business Unhealthy, institute given authority for handle the case of practice monopoly and competition of business unhealthy is Commission for the Supervision of Business Competition(CSBC). This institute to form based on the Legislations No 5 of 1999 and The Verdict of President No 75 of 1999. While the way handles the case to arrange in Article 38 until with Article 46 of Legislations No 5 of 1999 in connection with The Verdict of CSBC No: OS/KPPU/Kep/IX/2000.

According to Article 30 Paragraph 2 UU No. 5 of 1999, the commission is an institute independent regardless of influence and authorization of government along with another party. 
The commission consists of chairman person member, a vice double as member and at least 7 (seven) members. The member of commission appointed and stopped by president on the agreement PRC, while the time of position members of the commission is 5 (Five) years and can back appointed one of the positions to continue.

\section{b. Theory of Framework}

There are some theory to relevant with about strength to bind the verdict, that is :[4]

\section{1) The Theory of Law Material}

According to this theory, strength for the verdict usual mentioned "'gezag van gewijsde" have character of the law material, therefore organize about authority and obligations the court of justice, for example decide, delete or change. According to this theory, that verdict can to the surface or abolish relationship of the law. To mention as study of the law material because given cause to character of the law material in the verdict, to remember that verdict it only binds parties and not bind third parties. According to Professor Sudikno Mertokusumo, this theory not just because of not give the authority to maintain a person's right to the third.

\section{2) The Theory of Law Event}

According to this theory, the verdict not only resources of the law material but the source of on the power of prosesuil, who was in a verdict avowed as the owner that his with medium prosesuil about his opponent can act as the owner. This theory very narrow, cause the verdict not solely only source authority prosesuil, but also aim to determine definitely about relationships of the law is a basic of dispute.

\section{3) The Theory of Law Authentication}

According to this theory, the verdict is a proof of what is set forth that have a binding force because according to this theory of proving the opponent against a decision which has obtained permanent law force which is definitely not allowed. This theory to include ancient has not a lot of followers.

4) The Theory of Binding the Parties on the Verdict

Binding the parties on the verdict can have a positive meaning and the meaning of negative. The means a positive of the binding force on the verdict is that what has been terminated by the parties is applicable as a positive right, what has been terminated by judge must opinion right: "res judicata pro veritate habetur", binding the opponent not possible. Binding the parties it basic on the Article 1917 and 1920 KUH Civil. While means a negative for the binding force on the verdict is that may not break the case ever decided previously between the parties same with about main of the case same (nebis in idem, Article $134 \mathrm{Rv}$ ). A replay of this action will not have law effect.

\section{5) The Theory of Force of the Law of Definite}

A verdict obtains the force of the law of definite or constant (inkracht van gewijsde) if not again efforts of the law usual available, include efforts of the law usual that is opposition, appeal, and cassation. With obtain force of the law of definite and constant, so that verdict it's not again can change, although by a higher court, except with efforts of the law special, that is request civil and opposition the third parties.From the theorist above, can be used as the basis for determining the existence of a verdict made by an institution, if not fulfill requisite that thing, not verdict an institution the court. 


\section{Result and Discussion}

After the formation of CSBC, has some the case to finish and disconnected by CSBC, some between is a verdict which controversial and invitation argue the expert about the position or status of the law of verdict of CSBC, if have a binding force that is a verdict of institution the court. The main cause of the emergence of this problem is Constitution No 5 of 1999 as umbrella provision maintenance of the law competition efforts in Indonesia does not explicitly to clarify of CSBC is an institution juridical to replace the actor court in the cases of efforts competition.

Will, not other parties, Constitution has given to CSBC the authority opinion similar to an institution the court. The authority to include authority for investigating and break doubt administrative for the parties reputed contravene of Constitution No 5 of 1999.

On the basis is then used as the argument to consider of CSBC as institution have authority similar the institution juridical, with another word of CSBC same with operating guasi juridical, in the mean of CSBC authority for operating the function similar with function institution the court, that is checking and decide.

For the discussion how to the position or status of the law on the verdict of CSBC, necessary to know previously construction of the law, the character and implementation on the verdict issued by CSBC as implied in Constitution No 5 of 1999.

a. The Construction of the Law on the Verdict of CSBC

In the article 36, determine that of CSBC given the authority for decide and sets there or not infraction against of Constitution with dropped sanctions administrative against the report, In here then to appear of the problems, that is in the Constitution No 5 of 1999 not settle in distinct about format or the form on the verdict of CSBC, that to the surface interpretation or confusion of against the verdict of CSBC.

The difference with the construction of the law on the verdict another institute, for example arbitration. In the Constitution No 30 of 1999 about Arbitration, in Article 54 paragraph 1 of constitution, with clear to determine if the form or format the verdict to issued by arbitration of institution. In this Article, the verdict arbitration must load:[5]

" Head on the verdict, nickname the parties which dispute, a brief description of the dispute the establishment of the parties, name is Jengfap and arbitration address, consideration and conclusion of committee the arbitrage about totality of dispute, opinion in each arbitrage in things against difference opinion in committee of arbitrage, injection on the verdict, the place and date on the verdict and signature the arbitrage or arbitrage committee".

b. The Character on the Verdict of CSBC

If viewed from the character on the verdict to issued by CSBC, The Constitution No 5 of 1999 determine if the verdict to issued by CSBC the explain to prove guilty of the infraction against the Constitution No 5 of 1999, so that commission the authority in the verdict dropped sanctions in the form of action by CSBC does not authority using irah-irah, so he does not have the power of executorial.

c. The Implementation on the Verdict of CSBC

From the aspect of implementation, there are some of the verdicts of CSBC does not work by punished or punished not implementation on the verdict, so often in the case to character content of the parties the winner only got a difficult to force the victory opponents for fulfilling the obligation to in the verdict. 
The doubt and confusion in the implementation of the execution verdict of CSBC cause by not clear for the format or form on the verdict issued by CSBC. In the Constitution No 5 of 1999 also not settle in distinct about using words irah-irah. Based on theory and determine of constitution that verdict of judge have power executorial 70. The requisite on the verdict have power executorial is doing "For the Sake of Justice Based on An Impersonal Mighty Esa".

There is two characters to contains in the verdict to got execution, that is : (1). The Verdict on Condemnator, that is verdict to contains action of penalization against self defendant, in general against in the case conventional. The case of conventional a dispute or case to character party and there is party of defendant to submit accusation against defendant party, with process an examination in contradictory that is plaintiff party and defendant have right for responsible answer. (2) The Verdict on Declarator, that is verdict which injunction or decision only contains declaration of the law without together with condemnation. In general, this form of verdict against in the case to form volunteer that is case to form petition unilaterally, for example petition to submit request to court, so that appellant has position of certainty of the law bind on the self appellant alone, therefore verdict declarator don't have power of the law executorial.

To seen from character to contain in verdict like a writer to express above, so that verdict of CSBC can not input right in the verdict condemnation although verdict of declarator because verdict of CSBC only character administrative only.

\section{Conclusion}

In principle on the verdict to made of CSBC does not bind for the parties to dispute. Because in formal or normative of CSBC not authority made a verdict and given sanction that is justice. If seen from verdict to issued, does not include in the verdict of condemnatory although verdict of declarator. Therefore can writer to conclusion that position on the verdict to issued by CSBC in system of the law of Indonesia does not clear and confused. Does not clear because not settle in distinct by Constitution, confused because verdict can not input by CSBC only character administrative not juridical technical that is verdict other institutes out the court like is verdict P4P, Bapepam, BPSK, institute Arbitration, etc.

\section{Suggestion}

The Constitution No 5 of 1999 has not obtained until 7 years more found weakness and lack, one of about CSBC. Therefore it is better if made a change or revision of constitution so this business competition law in Indonesia can be enforced properly.

\section{References}

[1] Presiden Republik Indonesia, "UU Nomor 5 Tahun 1999 tentang Larangan Praktek Monopoli dan Persaingan Usaha tidak Sehat." 1999.

[2] M. D. Marwah and J. Emirzon, Aspek-Aspek Hukum Persaingan Bisnis Indonesia (Perjanjian yang dilarang, perbuatan yang dilarang dan posisi dominant). Unsri, 2003.

[3] B. K Harman and A. Hakim Garuda Nusantara, Analisa dan Perbandingan UU Anti Monopoli (UU Larangan Praktek Monopoli dan Persaingan Usaha Tidak Sehat). Jakarta: PT Elek Media Komputindo dan Bank Naskah Gramedia, 1999.

[4] S. Mertokusumo, Hukum Acara Perdata Indonesia. Yokyakarta: Liberty, 2013.

[5] Presiden Republik Indonesia, "UU Nomor 30 Tahun 1999 tentang Arbitrase dan 
Penyelesaian Sengketa.” 1999. 
